\title{
Germination of green and gray rubber rabbitbrush and their establishment on coal mined land
}

\author{
J.T. ROMO AND L.E. EDDLEMAN
}

\section{Abstract}

The objectives of this study were to: (1) determine the effects of temperature and water streas on germination, and; (2) evaluate effects of seeding date on emergence and survival of green and gray rubber rabbitbrush (Chrysothumurus nueseosus (Pallos) Britt. subsp. graveolens (Nutt.) Piper. and Chrysothamnus nauseosus (Pallas) Britt. subsp. nauseosus (Nutt.) Piper.). Seeds of both shrubs were incubated at 10,20 , and $30^{\circ} \mathrm{C}$ in a gradient of osmotic potentials ranging from 0.0 to $-1.5 \mathrm{MPa}$. Seedings were also made in the field on seeding dates over a period of 3 years. Total germination and germination rate declined as temperatures and osmotic potentials decreased; they were highest for both shrubs at 20 and $30^{\circ} \mathrm{C}$ and lowest at $10^{\circ} \mathrm{C}$. Under field conditions seedling populations were limited by low emergence and survival relative to viable seed planted. Emergence and survival of seedlings were highest in an exceptionally wet year, declining in subsequent years that were drier. Emergence ranged from 0 to $6.9 \%$ and 0 to $7.1 \%$ and survival of emerged seedlings ranged from 6.6 to $55 \%$ and 0 to $60 \%$ for green and gray rubber rabbitbrush, respectively. Survival of green rubber rabbitbrush was highest from mid-spring plantings, but no distinetively favorable seeding date was found for gray rubber rabbitbrush. Results sugzest that seeds of these shrubs should be planted prior to or during periods when seedbed temperatures are in the 20 to $30^{\circ} \mathrm{C}$ range and soil moisture is expected near its seasonal high.

Key Words: Chrysothamnus nauseosus, reclamation, seed ecology, water stress, native species, shrubs

Green rubber rabbitbrush (Chrysothamnus nauseosus (Pallas) Britt. subsp. graveolens (Nutt.) Piper.) and gray rubber rabbitbrush (Chrysothamnus nauseosus (Pallas) Britt. subsp. nauseosus (Nutt.) Piper.) are morphologically and ecologically distinct, but sympatric, subspecies that grow on the northern Great Plains. In many areas rabbitbrush is classified as undesirable by range managers. However, green and gray rubber rabbitbrush are important components of rangeland, adding structural and functional diversity. They show potential for use in reclaiming disturbed land by providing cover, stabilizing soils, moderating temperature and moisture regimes, providing forage for mule deer and pronghorn, and adding to the aesthetics. Most rabbitbrushes grow rapidly, produce abundant seed, but are not aggressive competitors with herbaceous plants (McArthur et al. 1979).

Green rubber rabbitbrush, a large shrub growing to $2 \mathrm{~m}$ tall, is common on south and southwest slopes of badland plant communities in southeastern Montana (Brown 1971). This shrub is an early successional species on a wide variety of soil textures on severely disturbed sites including borrow pits, road cuts, and spoil banks of coal and bentonite mines.

A smaller shrub, gray rubber rabbitbrush grows to 0.3 to $0.8 \mathrm{~m}$ tall. It is limited in its colonizing potential on drastically disturbed sites. Gray rubber rabbitbrush grows mainly on fine textured soils of ridges and slopes in good condition grassland communities

\footnotetext{
Authors are assistant professor, Department of Crop Science and Plant Ecology, University of Saskatchewan, Saskatoon, Saskatchewan S7N OW0 (Canada), and associate professor, Department of Rangeland Resources, Oregon State University Corvallis 97331 . At the time of this research the authors were research assistant and professor, University of Montana, Missoula, respectively.

Research was funded by the U.S. Department of Energy Grant EY-76-S-06-2232. Manuscript accepted 21 July 1988.
}

dominated by bluebunch wheatgrass (Agropyron spicatum (Pursh) Scrib. and Smith) and plains muhly (Muhlenbergia cuspidata (Torr.) Rydb.).

The basic requirements for germination and establishment must be elucidated for green and gray rubber rabbitbrush before they can be used to their fullest potential in reclaiming drastically disturbed lands. Objectives of this study were to: (1) determine the effects of temperature and water stress on germination of their seeds, and; (2) evaluate emergence and survival of these 2 subspecies of rubber rabbitbrush as influenced by timing of field plantings on reshaped coal mined land.

\section{Materials and Methods}

\section{Germination Experiments}

Seeds (achenes) of green and gray rubber rabbitbrush were harvested at the same site in October, 1979 and 1980, from several naturally established plants on unleveled spoilbanks at the Western Energy Coal Mine near Colstrip, Montana. Seeds were taken to the laboratory, dried at room temperature, cleaned as described by Eddleman (1977), and stored in paper envelopes in darkness in the laboratory at approximately $20^{\circ} \mathrm{C}$. A seedblower was used to remove empty seeds and provide uniform seed weights between years of collection.

Germination tests were conducted 14 and 4 months after collecting the seeds in 1979 and 1980 , respectively. Solutions of polyethylene glycol 6,000 (PEG) were prepared to depress osmotic potentials to $-0.3,-0.6,-0.9,-1.2$, and $-1.5 \mathrm{MPa}$ by adding PEG to distilled water (Michel and Kaufmann 1973). Distilled water was used as the control $(0.0 \mathrm{MPa})$. Osmotic potentials of these solutions, determined by psychrometric procedures, were within 0.05 to $0.18 \mathrm{MPa}$ of those desired. Seeds were dusted with captan (N-[(trichloromethyl)-thio]-cyclohexene-1,2-dicarboximide) to control fungi. Twenty-five of these seeds were placed in each petri dish on a 5-cm square of germination paper and $30 \mathrm{ml}$ of PEG solution were added. Petri dishes were covered and placed on trays on a water-saturated layer of germination paper, and the trays were enclosed in plastic bags to limit dessication. Seeds were incubated at constant temperatures of 10,20 , and $30^{\circ} \mathrm{C}$ without light. Germination was recorded at 2 -day intervals through 12 days and at 6-day intervals thereafter through 30 days. Seeds were considered germinated when cotyledons of seedlings were reflexed; seeds that failed to meet this criterion were judged abnormal.

Within subspecies, treatments were applied factorially to 4 replicates arranged in a randomized complete-block design using year of collection, temperature, and osmotic potentials as main treatments. Average germination rates $\left(\%\right.$ day $\left.^{-1}\right)$ were calculated according to Maguire (1962), and total germination was expressed as a percent. Percentage values were transformed with $\arcsin (\sqrt{p})$ and analyzed within subspecies using analysis of variance (Snedecor and Cochran 1980). Regression analysis was then used for untransformed data to develop response curves for each temperature and year of collection to determine the best fit regression equation (Steel and Torrie 1980). Because of the high probability of great variation in germination potential of different seedlots of native plants, responses to water stress between years and temperatures were compared. Confidence limits were computed for regression coefficients, allowing both comparison of water stress effects 

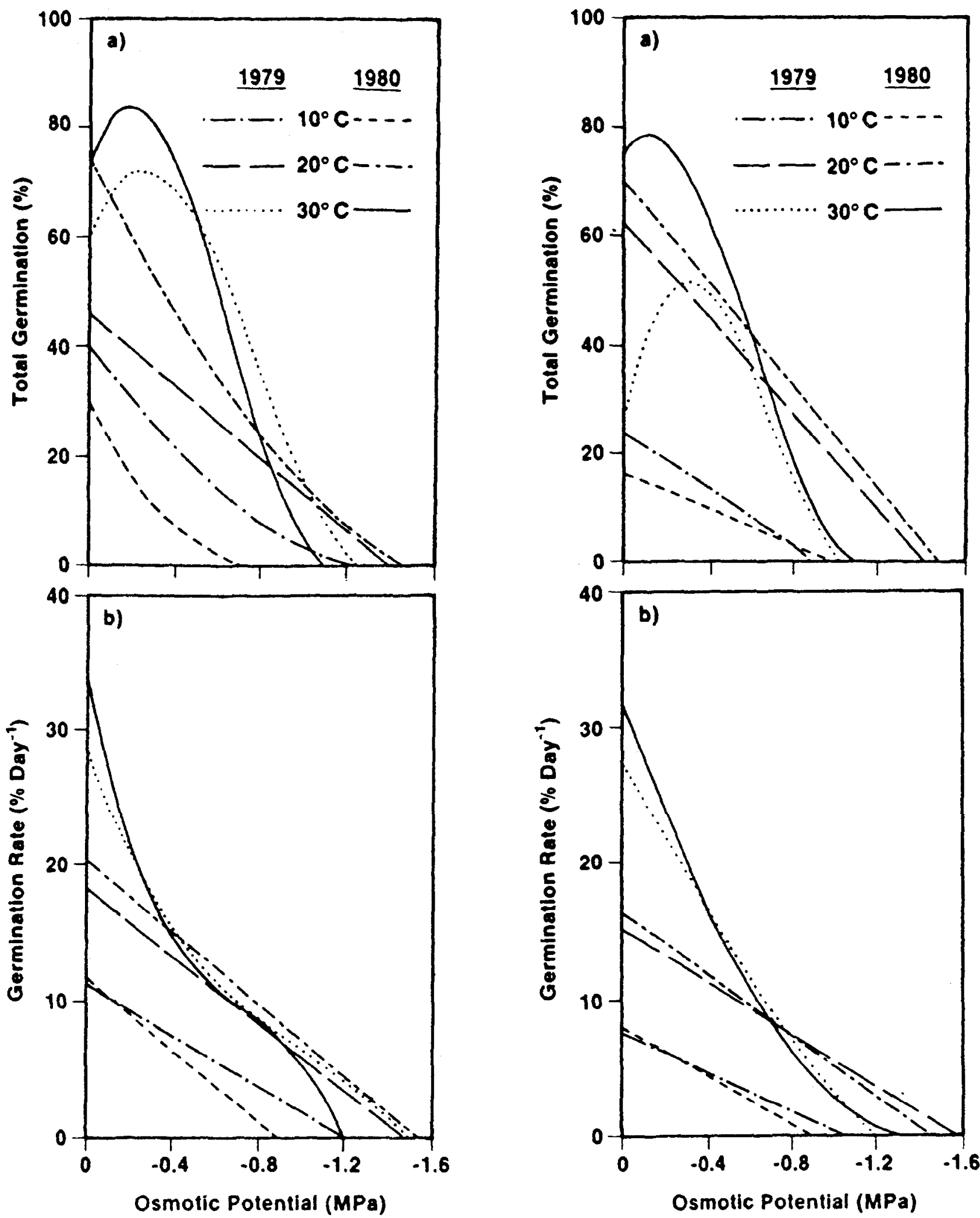

Fig. 1. Response curves for (a) total germination and (b) germination rate of green rubber rabbitbrush seeds collected in 1979 and 1980 and incubated at 10,20, and $30^{\circ} \mathrm{C}$ in a gradient of osmotic potentials (derived from regression analysis; see Table 1 ).

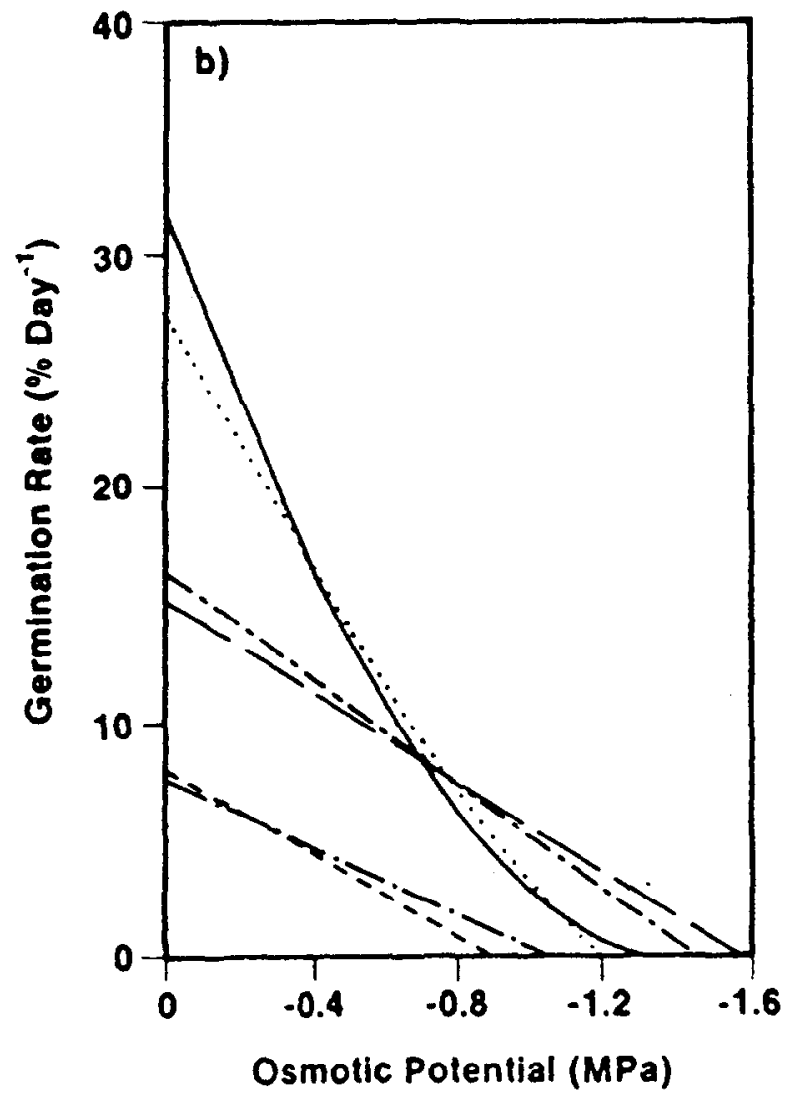

Fit. 2. Response curves for (a) total germination and (b) germination rate of gray rubber rabbitbrush seeds collected in 1979 and 1980 and incubated at 10,20, and $30^{\circ} \mathrm{C}$ in a gradient of osmotic potentials (derived from regression analysis; see Table 1 ). 
on total germination and germination rate among temperatures across years of collection.

\section{Emergence and Survival of Seedlings in the Field}

Emergence and survival were evaluated by sowing seeds of both shrubs on coal mined land that had been reshaped and topsoiled at the Western Energy Mine near Colstrip, Montana. Seeds were sown in early-spring (3 May 1979, 15 April 1980), mid-spring (10 May 1978 and 30 May 1979), and fall (25 October 1978 and 12 October 1979). Seeds collected in 1977, 1978, and 1979 were hand sown in 2-m rows at a depth of approximately $1 \mathrm{~cm}$ the year following collection. In 1978, 40 and 48 pure live seed (PLS) were sown per $m$ for gray and green rubber rabbitbrush, respectively. Seeding rates were increased to 200 PLS per $m$ for both subspecies in 1979 and 1980 in light of the low emergence recorded for the 1978 seedlings. Seedings were evaluated during their first growing season to determine seedling emergence; all plots were reevaluated in mid-summer 1981 to determine survival. Because seeding rates were not uniform among years, emergence was converted to a percentage of PLS and survival was expressed as a percent of seedlings that emerged. Data were transformed with $\arcsin (\sqrt{p})$ and analyzed within subspecies using analysis of variance with 5 replications in a randomized complete block design (Snedecor and Cochran 1980). Differences in significantly differing means for seedling emergence and survival were separated using Tukey's W-procedure (Steel and Torrie 1980).

\section{Results}

Germinntion Response to Temperature and Water Stress

Total germination and germination rate of both shrubs were highest at 20 and $30^{\circ} \mathrm{C}$ and lowest at $10^{\circ} \mathrm{C}$, and usually declined as osmotic potential decreased (Figs. 1 and 2). Germination of the 1979 collections was higher at $10^{\circ} \mathrm{C}$ than the 1980 collections, but at 20 and $30^{\circ} \mathrm{C}$ total germination of seeds from 1979 collections was lower than that for seeds collected in 1980.

Total germination and germination rate for green rubber rabbitbrush were related to the interaction of year of collection, temperature, and osmotic potential. The coefficients of regression equations for total germination were similar and germination declined in similar fashion within 10 and $30^{\circ} \mathrm{C}$ across years of collection (Table 1 and Fig. 1). Decline in total germination as osmotic potential decreased at $20^{\circ} \mathrm{C}$ was significantly different $(P \leq 0.05)$ between years. Regression coefficients for the total germination-osmotic potential relationships were significantly different ( $P \leq 0.05$ ) between temperatures for the 1979 collection, but were similar for seeds collected in 1980 and incubated at 10 and $20^{\circ}$ C. Within temperatures, shapes of the germination rate-osmotic potential relationships were similar across years (Table 1 and Fig. 1). When all temperatures were compared within years, slopes of germination rate versus osmotic potential were similar at 10 and $20^{\circ} \mathrm{C}$, but $30^{\circ} \mathrm{C}$ was distinct from the lower temperatures.

Total germination for gray rubber rabbitbrush was related to interaction of year, temperature, and osmotic potential; germina-

Table 1. Regrescion equationsa and coefiicients of determination for total germination and germination rate for green and gray rubber rabbitbrush collected 2 years and incubated at 10,20 , and $30^{\circ} \mathrm{C}$ in a gradient of oumotic potentials.

\begin{tabular}{|c|c|c|c|c|c|}
\hline Year $^{b}$ & Temperature $\left({ }^{\circ} \mathrm{C}\right)$ & Regression equation & & & $\mathbf{R}^{2}$ \\
\hline & & Green rubber rabbitbrush & & & \\
\hline $\begin{array}{l}1979 \\
1979 \\
1979\end{array}$ & $\begin{array}{l}10 \\
20 \\
30\end{array}$ & $\begin{array}{l}\text { Total germination }(\%) \\
Y=40.1+54.3 X+17.5 X^{2} \\
Y=45.5+32.5 X \\
Y=59.6-109.4 X-264.7 X^{2}-111.1 X^{3}\end{array}$ & $\begin{array}{l}\mathbf{a}^{\mathbf{c}} \\
\mathbf{b}\end{array}$ & & $\begin{array}{l}0.77 \\
0.85 \\
0.84\end{array}$ \\
\hline $\begin{array}{l}1980 \\
1980 \\
1980\end{array}$ & $\begin{array}{l}10 \\
20 \\
30\end{array}$ & $\begin{array}{l}Y=29.6+70.8 X+41.7 X^{2} \\
Y=73.8+77.8 X+18.7 X^{2} \\
Y=74.5-111.5 X-363.5 X^{2}-182.1 X^{3}\end{array}$ & $\mathbf{a}$ & $\mathbf{A}^{\mathbf{d}}$ & $\begin{array}{l}0.91 \\
0.92 \\
0.97\end{array}$ \\
\hline $\begin{array}{l}1979 \\
1979 \\
1979\end{array}$ & $\begin{array}{l}10 \\
20 \\
30\end{array}$ & $\begin{array}{l}\text { Germination rate }\left(\% \text { day }^{-1}\right) \\
Y=11.3+9.4 X \\
Y=18.4+12.4 X \\
Y=28.5+43.0 X+30.8 X^{2}+9.9 X^{3}\end{array}$ & $\begin{array}{l}\text { c } \\
\text { d } \\
\text { e }\end{array}$ & $\begin{array}{l}\text { B } \\
\text { B }\end{array}$ & $\begin{array}{l}0.76 \\
0.91 \\
0.97\end{array}$ \\
\hline \multirow[t]{2}{*}{$\begin{array}{l}1980 \\
1980 \\
1980\end{array}$} & $\begin{array}{l}10 \\
20 \\
30\end{array}$ & $\begin{array}{l}Y=11.7+12.9 X \\
Y=20.4+13.2 X \\
Y=33.7+75.9 X+87.6 X^{2}+39.7 X^{3}\end{array}$ & $\begin{array}{l}\mathbf{c} \\
\mathbf{d} \\
\mathbf{e}\end{array}$ & $\begin{array}{l}\mathbf{C} \\
\mathbf{C}\end{array}$ & $\begin{array}{l}0.88 \\
0.88 \\
0.95\end{array}$ \\
\hline & & Gray rubber rabbitbrush & & & \\
\hline $\begin{array}{l}1979 \\
1979 \\
1979\end{array}$ & $\begin{array}{l}10 \\
20 \\
30\end{array}$ & $\begin{array}{l}\text { Total germination }(\%) \\
Y=23.7+26.0 X \\
Y=63.2+44.5 X \\
Y=23.5-205.7 X-432.5 X^{2}-203.7 X^{3}\end{array}$ & $\begin{array}{l}\mathbf{a} \\
\mathbf{b} \\
\mathbf{c}\end{array}$ & & $\begin{array}{l}0.78 \\
0.88 \\
0.75\end{array}$ \\
\hline $\begin{array}{l}1980 \\
1980 \\
1980\end{array}$ & $\begin{array}{l}10 \\
20 \\
30\end{array}$ & $\begin{array}{l}Y=16.4+17.0 X \\
Y=70.9+48.1 X \\
Y=75.1-60.7 X-287.3 X^{2}-154.3 X^{3}\end{array}$ & $\begin{array}{l}\mathbf{a} \\
\mathbf{b} \\
\mathbf{c}\end{array}$ & & $\begin{array}{l}0.52 \\
0.83 \\
0.92\end{array}$ \\
\hline $\begin{array}{l}1979 \\
1979 \\
1979\end{array}$ & $\begin{array}{l}10 \\
20 \\
30\end{array}$ & $\begin{array}{l}\text { Germination rate }\left(\% \text { day }^{-1}\right) \\
Y=7.5+7.1 X \\
Y=15.11+9.6 X \\
Y=27.9+30.7 X+6.6 X^{2}\end{array}$ & $\begin{array}{l}\mathbf{a} \\
\mathbf{b} \\
\mathbf{c}\end{array}$ & $\mathbf{A}$ & $\begin{array}{l}0.76 \\
0.92 \\
0.90\end{array}$ \\
\hline $\begin{array}{l}1980 \\
1980 \\
1980\end{array}$ & $\begin{array}{l}10 \\
20 \\
30\end{array}$ & $\begin{array}{l}Y=7.9+8.6 X \\
Y=16.4+11.2 X \\
Y=32.0+43.8 X+14.8 X^{2}\end{array}$ & $\begin{array}{l}\mathbf{a} \\
\mathbf{b} \\
\mathbf{c}\end{array}$ & $\begin{array}{l}\mathbf{B} \\
\mathbf{B}\end{array}$ & $\begin{array}{l}0.68 \\
0.92 \\
0.95\end{array}$ \\
\hline
\end{tabular}

"Y is total germination or germination rate; $X$ is osmotic potential.

bindicates a year of seed collection.

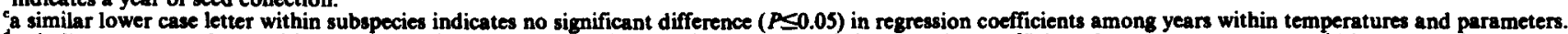

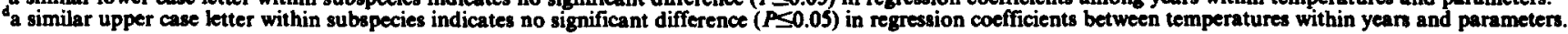


tion rate was affected by the interactions of temperature and osmotic potential and year and osmotic potential (Table 1). Regression coefficients for relationships between total germination and germination rate and osmotic potential were similar within temperatures and across years (Table 1 and Fig. 2). However, reduction in total germination as osmotic potential decreased was significantly different $(P \leq 0.05)$ between temperatures. Reduction in rate of germination as osmotic potentials declined was similar within temperatures across years; within years the response at $30^{\circ}$ $\mathrm{C}$ was distinct from 10 and $20^{\circ} \mathrm{C}$.

\section{Seedling Emergence and Establishment in the Field}

Precipitation received in 1978, 1979, and 1980 was reflected in emergence and survival of both shrubs (Table 2). Growing season

Table 2. Mean percent emergence in the year of seeding green and gray rubber rabbitbrush in 1978, 1979, and 1980 and survival of these seedlinga at Colstrip, Montana.

\begin{tabular}{|c|c|c|c|}
\hline Year & Seeding datel & $\begin{array}{l}\text { Emergence in } \\
\text { year of seeding } \\
(\%)\end{array}$ & $\begin{array}{c}\text { Survival in } \\
1981 \\
(\%)\end{array}$ \\
\hline \multicolumn{4}{|c|}{ Green rubber rabbitbrush } \\
\hline 1978 & $\mathbf{M S}^{2}$ & $2.8 \mathrm{~b}^{5}$ & $55.0 \mathrm{a}$ \\
\hline 1978 & $\mathbf{F}^{3}$ & $6.9 \mathrm{a}$ & $11.5 \mathrm{~b}$ \\
\hline 1979 & $\mathbf{E S}^{4}$ & $0.9 \mathrm{bc}$ & $6.6 \mathrm{~b}$ \\
\hline 1979 & $\mathbf{M S}$ & 0.9 bc & $55.0 \mathrm{a}$ \\
\hline 1979 & $\mathbf{F}$ & $0.0 \mathrm{c}$ & $0.0 \mathrm{~b}$ \\
\hline 1980 & ES & $0.0 \mathrm{c}$ & $0.0 \mathrm{~b}$ \\
\hline \multicolumn{4}{|c|}{ Gray rubber rabbitbrush } \\
\hline 1978 & $\mathbf{M S}$ & $2.0 \mathrm{~b}$ & $22.6 \mathrm{~b}$ \\
\hline 1978 & $\mathbf{F}$ & $2.3 \mathrm{~b}$ & $60.0 \mathrm{a}$ \\
\hline 1979 & ES & $7.1 \mathrm{a}$ & $22.0 \mathrm{~b}$ \\
\hline 1979 & MS & $0.9 \mathrm{~b}$ & $5.0 \mathrm{~b}$ \\
\hline 1979 & $\mathbf{F}$ & $0.2 \mathrm{~b}$ & $0.0 \mathrm{~b}$ \\
\hline 1980 & ES & $0.0 \mathrm{~b}$ & $0.0 \mathrm{~b}$ \\
\hline
\end{tabular}

'See text for seeding dates.

2MS indicates mid-spring seeding.

${ }^{3} \mathrm{~F}$ indicates fall seeding.

"ES indicates early spring seeding.

a similar letter within a subspecies and parameter indicates no significant difference $(P \leq 0.05)$ between seeding dates using Tukey's W-procedure.

precipitation received in 1978 and 1979 was among the highest and lowest, respectively, on record for Colstrip, Montana. From April through June 1978, $287 \mathrm{~mm}$ of precipitation were received, 59\% higher than the longterm mean. Conversely, during the same period in 1979 and 1980 , precipitation totaled $80 \mathrm{~mm}$ and $109 \mathrm{~mm}$, $55 \%$ and $39 \%$ lower than the longterm mean, respectively. Carryover effects of the above-average precipitation in 1978 and low precipitation in 1979 and 1980 were presumably mirrored in declining emergence and survival in 1979 and 1980 as compared to 1978.

Emergence of green rubber rabbitbrush ranged from 0 to $6.9 \%$ and survival of these seedlings from 6.6 to $55 \%$ (Table 2). Although emergence was inconsistent among seeding dates, survival was significantly $(P \leq 0.05)$ higher from mid-spring seedings than from sowings in early spring and fall. There was no clear trend established in the most favorable time for emergence and survival of gray rubber rabbitbrush (Table 2). Emergence ranged from 0 to $7.1 \%$ and survival of these seedlings ranged from 0 to $60 \%$.

\section{Discussion}

Green and gray rubber rabbitbrush germinated over a broad range of temperatures but a narrow range of water stress. When germination under water stress is considered in the context of total and rate, results of this study indicate that temperatures between 20 and $30^{\circ} \mathrm{C}$ were near optimal. At 10 and $20^{\circ} \mathrm{C}$ total germination and germination rate declined as water stress increased. Although total germination at $30^{\circ} \mathrm{C}$ was higher at low levels of water stress relative to the control, germination rate subsequently declined as water stress increased. Interacting effects of temperature and water stress on germination have also been shown for other shrubs with germination under water stress highest at optimal temperatures (Weldon et al. 1959, Springfield 1968, Romo and Eddleman 1985).

Eddleman (1977) concluded that temperatures higher than $20^{\circ} \mathrm{C}$ appeared optimal for germination of these shrubs; germination was reduced and slower at lower temperatures. Similarly, Sabo et al. (1979) reported germination was best at warm temperatures for Chrysothamnus nauseosus (Pallas) Britt. subsp. consimilis (Greene) H.M. Hall and Chrysothamnus nauseosus (Pallas) Britt. subsp. bigelovii (Gray) H.M. Hall from New Mexico. Germination of $C$. nauseosus subsp. consimilis was highest at alternating temperatures between 13 and $27.5^{\circ} \mathrm{C}$, and $\mathrm{C}$. nauseosus subsp. bigelovii germinated best at alternating temperatures between 20.5 and $30^{\circ}$ C.

Results of the germination experiments and field plantings emphasize the importance of maintaining high levels of soil moisture for maximizing germination and emergence of green and gray rubber rabbitbrush. Their emergence and establishment were severely limited in dry years. A sharp contrast in establishment of several shrubs, grasses, and forbs in wet and dry years was also reported by Eddleman (1980). In the present study seedling populations were limited in the field by low emergence and survival a characteristic also common to Chrysothamnus nauseosus (Pallas) Britt. subsp. albicaulis (Nutt.) Rydb. (Stevens et al. 1986).

The present tests indicate that germination, emergence, and survival can be expected from any season of planting. However, to maximize germination of green and gray rubber rabbitbrush, seeds should probably be sown prior to times when seedbed temperatures are in the 20 to $30^{\circ} \mathrm{C}$ range when soil moisture is expected near field capacity. On the northern Great Plains, April through June is the period with highest amount and the greatest probability of precipitation being received (Caprio et al. 1980). Generally June receives the most precipitation and July is the hottest month. Seedlings of rubber rabbitbrush are sensitive to frost and drought (Plummer et al. 1968) thus, the window for germination, emergence, and establishment may be limited by low spring temperatures and by summer drought. These relationships therefore suggest that seeds should be sown in May through early June to take advantage of favorable temperatures and soil moisture to maximize germination and the period of growth for seedlings.

Mackey and Depuit (1985) suggested that rabbitbrush has a broad ecological tolerance and should be considered for use in reclamation. Reclamation specialists have ready access to plant materials in green and gray rubber rabbitbrush since seeds of locally adapted ecotypes are available near most mines on the northern Great Plains and seeds can be easily collected. Rabbitbrush seeds also germinate well (Plummer et al. 1958, Eddleman 1977, Sabo et al. 1979), and those collected in the fall can be sown the following year (Eddleman 1977). These shrubs should be considered for use in reclaiming drastically disturbed land because of their rapid growth and reseeding characteristics, and because they may ameliorate moisture and temperature regimes and provide late season forage for wildlife. They are native species that can add to the structural and functional diversity on reclaimed land that is required by law.

\section{Literature Cited}

Brown, R.W. 1971. Distribution of plant communities in southeastern Montana badlands. Amer. Midl. Natur. 85:458-477.

Caprio, J.M., Snyder, R.D., and G.K. Grunwald. 1980. Precipitation probabilities in Montana. Montana Agr. Exp. Sta. Bull. 712.

Eddleman, L.E. 1977. Indigenous plants of southeastern Montana. I. Viability and suitability for reclamation in the Fort Union Basin. Montana Forest and Conserv. Exp. Sta. Spec. Pub. 4.

Eddleman, L.E. 1980. Coal mine reclamation with native plants. Proc. of Symp. on Watershed Management, ASCE, p. 80-90, Boise.

Mackey, C.V., and E.J. Depuit. 1985. Natural revegetation of surfacedeposited spent oil shale in Colorado. Reclam. Reveg. Res. 4:1-16. 
Maguire, J.D. 1962. Speed of germination-aid in selection and evaluation of seedling emergence and vigor. Crop Sci. 2:176-177.

McArthur, E.D., A.C. Blauer, A.P. Plummer, and R. Stevens. 1979. Characteristics and hybridization of important Intermountain shrubs. III. Sunflower family. USDA Intmtn. Forest and Range Exp. Sta. Res. Paper INT-220.

Michel, B.E., and M.R. Kaufman. 1973. The osmotic potential of polyethylene glycol 6,000. Plant Physiol. 51:914-916.

Plummer, A.P., Christemen, D.R., and S.B. Monson. 1968. Restoring big game range in Utah. Utah Division of Fish and Game. Pub. 68-3.

Romo, J.T., and L.E. Eddleman. 1985. Germination response of greasewood (Sarcobatus vermiculatus) to temperature, water potential, and specific ions. J. Range Manage. 38:117-120.

Sabo, D.G., Johnson, G.V., Martin, W.C., and E.F. Aldon. 1979. Germination requirements of 19 species of arid land plants. USDA Rocky Mtn. Forest and Range Exp. Sta. Res. Pap. RM-210.
Snedecor, G.W., and W.C. Cochran. 1980. Statistical methods. The Iowa State University Press, Ames.

Sprinfield, H.W. 1968. Germination of winterfat seeds under different levels of moisture stress and temperatures. J. Range Manage. 21:314-316. Steel, R.G.D., and J.H. Torrle. 1980. Principles and procedures of statistics. McGraw-Hill Book Co., New York.

Stevens, R., Jortencen, K.R., Davis, J.N., and S.B. Monsen. 1986. Seed pappus and placement influences on white rubber rabbitbrush establishment. p. 353-357. In: Proc. Symp. on the Biology of Artemisia and Chrysothamnus. USDA Intermountain Forest and Range Exp. Sta. Gen. Tech. Rep. INT-200.

Weldon, LW., Bohmont, D.W., and H.P. Alley. 1959. The interrelation of three environmental factors affecting germination of sagebrush seed. J. Range Manage. 12:236-238. 